\title{
Literatura macedońska dla dzieci (rekonesans badawczy)
}

\begin{abstract}
This short study embraces both the first sprouts of the written Macedonian literature for children (somewhere around the second part of the $19^{\text {th }}$ century), and the literary production which happens after the establishment of the contemporary Macedonian language, that is, after the 1945. Still, the main accent is on two newer books: Verses also Grow (И cmpoøume pacmam) by Alexandar Kujundziski and Jump and Skip (Скокни прескокни) by Vasil Mukaetov which is a part of the refreshed reading list as an optional book for the Macedonian language lessons in the primary schools in Macedonia. Both authors put an emphasis exactly on a child's sensitivity and such issues as character growth and maturation. In their books, they transfer the reader from childhood to adulthood unnoticeably and lightly. Their message is to help the little human in the complex process of his or her own comprehension and to show him or her that he or she are not alone in this process.
\end{abstract}

Key word s: Macedonian literature for children, sensitivity, maturation

Literatura dla dzieci wywodzi się według niektórych z tzw. folkloru dla dzieci, co tylko potwierdza tezę o jej ludowym rodowodzie. Według innych jej źródeł należy szukać jeszcze przed epoką antyczną oraz w jej trakcie - zwraca się tym samym uwagę na matrycę mitologiczną literatury dla dzieci. Jeszcze inni badacze tylko częściowo przyjmują dwa pierwsze poglądy, twierdząc, że literatura ta „wraz ze swoimi cechami stylistycznymi i względami pedagogicznymi powstaje w czasach Puszkina, braci Grimm, Andersena, Juliusza Verne’a i Lewisa Carrolla" (Drugowac, 1996, s. 7).

Pierwsze ślady (za)pisanej macedońskiej literatury dziecięcej odnajdujemy w:

- scenkach dialogowych Jordana Hadżi Konstantinowa oraz w jego pierwszym elementarzu Tablica perwaja z drugiej połowy XIX wieku;

— „Zbiorze” (mac. „Зборник”) braci Miladinowów z 1861 roku;

- nieopublikowanych wierszach dla dzieci autorstwa Grigora S. Prliczewa z 1872 roku; 
- folklorystycznym dziele autorstwa Kuzmana A. Szapkarewa i Marka K. Cepenkowa z końca XIX i początku XX wieku.

Folklor dla dzieci ma długą i bogatą tradycję, a jako odrębne zjawisko jest opisywany w klasyfikacjach zarówno Karadzicia, jak i macedońskich zbieraczy oraz badaczy folkloru - Miladinowa, Szapkarewa czy Cepenkowa. W Zbiorze braci Miladinowów folklor ten, a dokładniej: krótkie wierszyki-enigmy, nazwane są igraszkami (mac. играчкu - pol. „zabawka”, ,igraszka”), u Szapkarewa funkcjonują jako wierszyki czy powiedzonka, natomiast Cepenkow twórczość tego typu uznaje za bliższą zabawy/gry dziecięcej. Macedońskie słowo играчки istnieje i dziś, ale rzeczownik ten

stosujemy na oznaczenie przedmiotów z różnorodnych materiałów, przedmiotów zrobionych ręcznie (wobec czego pełnych uczuć) lub też wykonanych fabrycznie (najczęściej z metalu, gumy czy plastiku), umilających dzieciństwo, dających możliwość zabawy i lepszego wejścia w dorosłość.

Władowa, 2001, s. 50

Zabawki, zarówno w najbiedniejszym, jak i najzamożniejszym domu, są ważnym elementem okresu dzieciństwa. Można uznać, że dzieciństwo wielkich macedońskich odrodzeniowców XIX wieku wypełnione było najsubtelniejszymi i fantastycznymi zabawkami pełnymi ludzkiego ducha i dowcipu, stworzonymi jedynie ze słów. W dziecięcych grach językowych sens najczęściej staje się ofiarą rytmu i dźwiękowych asocjacji. W dużej mierze są one mętne i „potrafią wybrzmieć dość nielogicznie, co jednak nie pozbawia ich uroku relacji opartej na asonansie, aliteracji i rymie. Celem tych form [...] jest gra sama w sobie" (Władowa, 2001, s. 51).

Dopiero jednak opracowanie macedońskiego alfabetu (5 maja 1945 roku) i zasad pisowni (7 czerwca 1945 roku) umożliwiło wydanie pierwszego elementarza nowo skodyfikowanego języka. Decyzję o wydaniu takowego elementarza podjęło prezydium ASNOM (Antyfaszystowskiej Rady Wyzwolenia Narodowego Macedonii) 16 kwietnia 1945 roku, inicjując jednocześnie powstanie Państwowego Instytutu Wydawniczego Macedonii, późniejszego wydawnictwa Proswetno delo. Po kilku miesiącach wydało ono dzieło pod tytułem Elementarz z czytanka dla klasy pierwszej (96 stron), które jest dziełem komisji powstałej z ramienia ówczesnego Ministerstwa Oświaty Narodowej Macedonii. O wizualną stronę elementarza zadbał Wasilie Popowić-Cico.

Czytanka, która jest integralną częścią elementarza, zawiera oprócz pieśni i opowieści ludowych (zarówno macedońskich, jak i rosyjskich) także teksty autorskie pióra Wasyla Kunoskiego, Wancza Nikoleskiego, Lazego Karowskiego, Slawka Janewskiego czy Joncza Josifowskiego. Z Katalogu ksiag wydanych nakładem Państwowego Instytutu Wydawniczego w latach 1945, 1946, 1947 i $1948^{1}$

\footnotetext{
${ }^{1}$ http://www.slideshare.net/OnlineEduCenter/katalog-8590003 [data dostępu: 26.09.2018].
} 
wynika, że już w 1946 roku wychodzą pierwsze książki dla dzieci: Mały Macedończyk (Македонче) - zbiór wierszy (46 stron), Mice (Мuще, opowieść ludowa wierszem, 24 strony) autorstwa Wancza Nikoleskiego, następnie wierszowane Rozśpiewane litery (Распеани букви, 64 strony $^{2}$ ) oraz Pionierzy, pionierki, robaczki i leśne bestyjki (Пионери, пионерки, бубачки и шумски sверки) - ороwieści Slawka Janewskiego (61 stron), jak również pisany wierszem Pastuszek (Овчарче) autorstwa Lazego Karowskiego (31 stron), w których widoczny jest wpływ kultury ludowej.

Prostota staje się zaletą i jednocześnie cechą charakterystyczną pierwszego w macedońskim języku ogólnym zbioru dla dzieci, „która w całości”, według Murisa Idrizowicia, nie wynika „z kreatywnego stosunku do rzeczywistości, ale z potrzeby czasów" (Idrizowić, 1988, s. 28). W tym więc kontekście znane wersy, nieobce przynajmniej tym, których dorastaniu towarzyszyły, nie wychodzą poza ramy tzw. pieśni edukacyjno-poznawczej: „Małym jeszcze jestem dzieckiem, / i odważnym bohaterem, / synem ziemi mojej miłej, / synem Macedonii” („Малечко сум уште дете, / јуначе сум смело јас, / син на лична земја мила, / син на Македонија", суt. za: Idrizowić, 1988, s. 28). W takim kontekście Wanczo Nikoleski jako jeden z pierwszych nauczycieli języka macedońskiego we wsiach okolic wyzwolonego Debarca z całą odpowiedzialnością nosi miano „ojca i pierwszego pióra" literatury dla dzieci w Macedonii (Drugowac, 1996, s. 82). Także zbiór Pastuszek Lazego Karowskiego, mimo łaskawych słów Dimitara Mitrewa, z dzisiejszego punktu widzenia, według Idrizowicia, „ma charakter bardziej historyczno-literacki, podczas gdy jego wartość literacka jest skromna". Jest ona interesująca ,jako dokument tematycznej i wyrażeniowej przynależności", ponieważ zbiór pełni funkcję wychowawczą, jak podsumowuje Idrizowić (Idrizowić, 1988, s. 108), choć Drugowac zauważa, że „Poeta zwraca się w stronę doświadczenia macedońskiej pieśni ludowej, ale pojawia się również próba zerwania z jej słownikiem i formułą melodyczną" (Drugowac, 1996, s. 197).

Zupełnie inna wydaje się literatura, jaką proponuje Slawek Janewski. W jego pierwszych książkach wyczuwa się nakierowanie na pewną "grę”, jest także widoczne włączenie poważnych „elementów nowoczesności” (Idrizowić, 1988, s. 82). Dlatego też uważa się, że to właśnie Janewski „położył fundament pod nowoczesne słowo i wiersz w macedońskiej poezji i prozie" dla dzieci (Idrizowić, 1988, s. 94). Według Janewskiego, literatura dla dzieci nie powinna być dydaktyczna: „Nigdy nie staram się jej takową czynić. Jeśli jednak nauczyciele i profesorowie w którymś z moich tekstów znajdą coś, co może czegoś dzieci nauczyć — niech z tego swobodnie skorzystają" (cyt. za: Drugowac, 1996, s. 139).

Właśnie taka jest opowieść Car Tyfus, księżniczka Goraczka i inni źli władcy (ze zbioru Pionierzy, pionierki, robaczki i leśne bestyjki), która dzięki grze i nie-

${ }^{2}$ http://okno.mk/sites/default/files/097-Raspeani-bukvi-Slavno-Janevski.pdf [data dostępu: 26.09.2018]. 
typowym doświadczeniom chłopca o imieniu Koczo nienatarczywie przekazuje edukacyjne treści na temat higieny. Wspomniany Koczo jest „zatwardziałym wrogiem wody i mydła”, czy też mydło i woda są jego największymi wrogami, i dlatego zaraża się wszystkimi możliwymi znanymi chorobami, co kończy się pobytem chłopca w szpitalu.

Oprócz pionierów i pionierek w opowieściach tych dużą rolę odgrywają także zwierzęta i rośliny albo - jak mówi sam Janewski - robaczki i leśne bestyjki, a w tej konkretnej opowieści także mydło i woda. Czy raczej odwrotnie. Przygody robaczków i leśnych bestyjek stają się doświadczeniem pionierów i pionierek. Na marginesie rozważań warto również odnotować zbiór Pieśni ludowe dla dzieсі (Народни песни за деца, 51 stron) z 1946 roku pod redakcją Wancza Nikoleskiego i Joncza Josifowskiego, z ilustracjami Slawka Janewskiego.

Artykuł stanowi próbę pokazania ponadsiedemdziesięcioletniej tradycji literatury dziecięcej, od pierwszych książek napisanych po macedońsku przez kultową Cukrowa opowieść (Шеќерна приказна, 1952) Slawka Janewskiego, zbudowaną na matrycy macedońskiej baśni ludowej czerpiącej z ludowej baśni europejskiej i literackiej, aż do najnowszych, jak $W$ drodze do Taratambo ( $\mathrm{Ha}$ nam за Таратамбо, 2016) autorstwa Trajczego Kacarowa. Magiczna ziemia robaczków i leśnych bestyjek (Janewski) zmienia się w jeszcze cudowniejszą krainę o niezwykłej nazwie - Taratambo (Kacarow), która przypomina Nibylandię Piotrusia Pana, krainę czarów, do której trafia Alicja, krainę wiecznej zabawy Pinokia, czy też Negobilo, w którym rodzi się cukrowe dziecko Slawka Janewskiego.

Kilka lat temu zrewidowano listę lektur od klasy II do IX szkoły podstawowej. Pojawiły się konkretne propozycje i nowy program oferty czytelniczej. Oprócz znanych nazwisk i tytułów zarówno rodzimej, jak i światowej literatury dla dzieci włączono do niej autorów, którzy zostali skonfrontowani z pisarzami tworzącymi od lat nie tylko kanon macedońskiej literatury dla dzieci i młodzieży, np. Zoki Poki (Зоки Поки) сzy Dziewczyny Marka (Девојките на Марко) Oliwery Nikolowej, Jedz i rośnij (Касни - порасни) Petrego M. Andreewskiego, Cukrowa opowieść Slawka Janewskiego, Duzi i mali (Големи и мали) Boszka Smacioskiego, Spomenka (Споменка) i Marta (Mapma) Gorjana Petreskiego, ale również kanon światowy (Pipi Pończoszanka Astrid Lindgren czy Pinokio Carla Collodiego i Mały Ksiażze Antoine’a de Saint-Exupery'ego).

W 2013 roku do pierwszego po rewizji spisu lektur weszli więc ostatni laureaci Nagrody im. Wancza Nikolewskiego (nagroda Stowarzyszenia Pisarzy Macedońskich): Eftim Kletnikow i jego Car Sałtan (Цар Салтан, nagroda za 2010 rok) oraz Biljana Stankowska i jej Prawdziwa opowieść o znikaniu opowiеści (Вистинска приказна за исчезнуваюето на приказните, nagroda za 2011 rok). Pierwsza napisana została na motywach bajki o tym samym tytule autorstwa Aleksandra Puszkina i jest wierszowanym dramatem w sześciu ak- 
tach. Utwór już przy pierwszym czytaniu wydaje się odpowiedni do przedstawienia scenicznego. Natomiast Stankowskiej, otwarcie mówiącej o strachu przed całkowitym zniknięciem opowieści, udaje się bez moralizatorskiego tonu przekazać konkretne, ważne dydaktycznie i humanistycznie przesłanie o znaczeniu rodziny, miłości, wdzięczności, uczciwości czy dotrzymywania obietnicy. Przyszli czytelnicy wraz ze swoimi nauczycielami otrzymali możliwość (prócz światowych i macedońskich klasyków) wyboru nowszego tytułu autorów macedońskich, jak np. Lubię książkę (Сакам книгa) Aleksandra Kujundżiskiego, przetłumaczoną na sześć języków mniejszościowych w Macedonii (albański, turecki, serbski, romski, arumuński i bośniacki), a także od 2016 roku na cztery inne (słoweński, chorwacki, czarnogórski i niemiecki) czy Złote jabłko i inne bajki (Златното јаболко и други бајки) Hrista Petreskiego.

W międzyczasie napisano i wydano sporo nowych książek, a wśród nich kilka jest naprawdę wyjątkowych, np. Dzieła zebrane Wasyla Kunowskiego (2010), które przypomniały czytelnikom o wielu zapomnianych już kwestiach, związanych z nim jako człowiekiem, mężem, ojcem, dziadkiem, ale przede wszystkim jako wielkim poetą dla dzieci w Macedonii, tłumaczonym na kilka języków (serbski, chorwacki, słoweński, albański, turecki i rosyjski). Jego teksty przypomniały o konieczności opowiadania, czytania i recytowania dzieciom.

Niektórzy autorzy świętowali okrągłe jubileusze: w 2013 roku z okazji pięćdziesięciolecia twórczości oraz pięćdziesięciolecia wydania książki Zoki Poki ukazały się trzytomowe Dzieła zebrane dla dzieci Oliwery Nikolowej (Czy twoje serce bije dla mnie?, Czy moje serce bije dla ciebie? i Czy nasze serca bija dla nas?). Jubileusz to zasłużony, gdyż w okresie swoich intensywnych pięćdziesięciu lat twórczości adresowanej nie tylko do dzieci, ale również do dorosłych Nikolowa udowadnia, że przez tekst można okazać szacunek dziecku.

Stowarzyszenie Pisarzy Macedońskich każdego roku z zaangażowaniem śledzi produkcję książek kierowanych do najmłodszych czytelników i stara się, by Nagroda im. Wancza Nikoleskiego trafiała w odpowiednie ręce. W ostatnich latach jednak, tj. od 2010 roku, nie zdobył jej żaden nowy autor książek dla dzieci. Laureatami tej prestiżowej nagrody są Pande Manojlow (ur. 1948) za zbiór poezji Śnij dobro (Сонувај добрина, Skopje, 2012), Aleksandar Kujundżiski (ur. 1946) za zbiór poezji I strofy rosna (И cmpoøume pacmam, Skopje, 2013), Stojan Tarapuza (ur. 1933) za zbiór poezji Namalowany czas (Насликано време, Skopje, 2014), Welko Nedelkowski (ur. 1946) za książkę, czy raczej serię powieści, Zlatko-Zlatec (Златко-Златеu, Skopje, 2015), Aleksandar Popowski (ur. 1932) za książkę I po raz setny (И no cmonamu, Skopje, 2016) oraz Wasyl Mukaetow (ur. 1941) za zbiór poezji Skocz i przeskocz (Скокни, прескокни, Skopje, 2017). Wszyscy laureaci to siedemdziesięcio- i osiemdziesięcioletni autorzy.

Każde dziecko powinno wypracować nawyk, najpierw słuchania, a potem czytania. W tej kwestii ważną rolę odgrywają książki ilustrowane, dzięki którym dziecko zaczyna rozwijać potrzebę słuchania, a ta w późniejszym okresie 
przeradza się w potrzebę (samodzielnego) czytania. Książka ilustrowana poprzedza książki dla dzieci i książki w ogóle. Jest ona „książką, w której ilustracje odgrywają znaczącą rolę w procesie opowiadania. [...] Tym, co czyni książkę ilustrowaną unikatową formą artystyczną, jest fakt, że tekst i obraz przyczyniają się do całkowitego zrozumienia dzięki współdziałaniu rytmu, ruchu, napięcia, wyglądu strony i całościowego projektu" (Todorowa, 2012, s. 49). W rzeczywistości specyficzna poetyka książki ilustrowanej powoduje, że jej odbiorca jest jednocześnie widzem i słuchaczem, i z tej perspektywy wyłania się nowy czytelnik. Kiedy opowieść dla dzieci czytana jest na głos, przypomina przedstawienie teatralne czy też film, twierdzi Rita Oittinen (cyt. za: Todorowa, 2012, s. 51). Współczesne dziecko o wiele bardziej/intensywniej percepuje świat wizualnie, co najwyraźniej dostrzega kapituła Nagrody im. Wancza Nikoleskiego, honorując pozycje poświęcające szczególną uwagę również stronie wizualnej, tj. artystycznemu i graficznemu kształtowi, dzieła.

W krótkim studium służącym zapoznaniu się ze współczesną macedońską literaturą dla dzieci chciałabym zwrócić uwagę na dwie nowsze pozycje na rynku, z których jedna wchodzi w skład odświeżonego spisu lektur jako lektura do wyboru. Ważne jest jednak, by o prawdziwą dynamikę i świeżość pytać młodych. Czy to, co my, dorośli i kompetentni czytelnicy, wybieramy dla dzieci, na pewno im odpowiada? Czy pozycje te dobrze się czyta, czy są ekscytujące, żywe, czy skłaniają do przemyśleń? Po takie należy sięgać!

\section{Uczyć się liczyć, uczyć się czytać, by dorosnąć naprawdę}

Sto dziesiąta z rzędu książka opublikowana przez Aleksandra Kujundżiskiego pod tytułem I strofy rosną to opowieść o współczesnym dziecku, które rosnąc, opanowuje równolegle litery (trzydzieści jeden w alfabecie macedońskim) i cyfry (piętnaście według koncepcji poety). Tom I strofy rosna zawiera trzydzieści dwa wiersze (pierwsze cztery z jedną strofą dwuwierszową, a dwa ostatnie po piętnaście strof czterowierszowych), których zwrotki dosłownie „rosną”, tak samo jak rosną, tj. powinni rosnąć sami czytelnicy, od tych najmniejszych przez tych trochę większych, jeszcze większych, aż do dużych.

„Poezja i matematyka to dwie pokrewne dyscypliny”, zaznaczają i Poe, i Baudelaire, i Mallarmé. Według takiej koncepcji, słowa to językowe symbole, dzięki którym możliwe jest dokonywanie precyzyjnych operacji myślowych, jak w matematyce. To właśnie matematyczna dokładność stylu umieszcza Baudelaire’owskie Kwiaty zła wśród najbardziej wymagających dzieł liryki europejskiej. Uważa się, że tendencja twardej i logicznej architektury tomu, czyli surowo określonego w nim porządku wierszy, jest charakterystyczna dla nowoczesnej poezji. W taką koncepcję twardej i logicznej architektury poetyckiej wpisuje się Aleksandar Kujundżiski ze swoim tomem I strofy rosną. 
Tak jak tom Petrego Andreewskiego Jedz i rośnij (1992) próbuje uczynić świat bardziej interesującym, barwnym i smaczniejszym, stawiając małego czytelnika przed koniecznością wyboru, który owoc jest ulubiony, który owocowy cukierek zjeść dzisiaj, a który zostawić sobie na jutro, jednocześnie pozwalając mu powoli i bez zmartwień rosnąć, także zbiór Aleksandra Kujundżiskiego I strofy rosna (2013) pokazuje małemu czytelnikowi, jak litera za literą, słowo za słowem, najpierw wymówionym, a potem przeczytanym, zaczyna tworzyć się myśl, i jak te myśli zaczynają się układać, strofy rosnąć, wiersze liczyć i przeliczać, małe opowiastki stają się wielkimi opowieściami, a proste — złożonymi. Jak życie! Należy się uczyć liczyć, czytać, jeśli chcemy dorosnąć naprawdę!

Cały tom, prócz ścisłej formuły matematycznej polegającej na tym, że każdy kolejny wiersz ma jedną strofę więcej od poprzedniego, a także reguły, że każda strofa ma swoją parę, jest pomyślany jak baśń. Poeta Kujundżiski swoje baśniowiersze buduje, przyjmując za punkt wyjścia strukturę nici, frekwencję dialogową, wybór postaci, sześciozgłoskowiec, temat. Można się pokusić o twierdzenie, że baśniowe wiersze autora przewyższają znany schemat baśni Ezopa, Obradovicia, Kryłowa, Lessinga. Tom ten tworzy pewien własny baśniowiersz, w który przetransponowany zostaje czas współczesny poecie, ale też dziecku. Widać to szczególnie w obrazach poetyckich opartych na elementach współczesnej technologii, które są częścią życia najmłodszych i częścią ich dzieciństwa. Mamy więc sójkę, która całymi dniami śledzi, co się dzieje w Internecie, wysyła jaskółce jaja kurierem, a w rozmowie między gołębiem dzikim i domowym ten drugi radzi krewnemu, by jego wolny kuzyn jak najszybciej zaczął uczyć się obsługi komputera.

Trzeba przyznać, że baśń toczy bój o przetrwanie. Mierzy się z ekspansją mediów wizualnych i elektronicznych, które dominują nad literaturą. Baśnie poetyckie mogą przyciągać dzieci. W literaturze tej odnajdujemy treść radosną, prowokującą do niepohamowanego śmiechu i łez. Wiersze Kujundżiskiego mówią przede wszystkim o naszym kulturowym i życiowym doświadczeniu, a także o małych wielkich sprawach, które czynią nasze życie istotnym. To nie tylko literatura pedagogiczna, deklaracyjna czy też estetyczna enigmatyczność, to wersy, które niosą radość i naukę jednocześnie.

W wierszach Kujundżiskiego nie ma bohaterów zwierzęcych charakterystycznych dla Ezopa czy La Fontaine’a, a nawet jeśli jakieś się pojawiają, to są już przekształcone, wobec czego zyskują nowe znaczenia. Baśniowe wiersze Kujundżiskiego pełne są za to kryształowych, typowych atrybutów bohaterów zwierzęcych, którzy toczą niezwykłe i niecodzienne rozmowy. Wymądrzają się między sobą wąż i wół, mucha i pszczoła kłócą się o to, czyje brzęczenie przynosi większą korzyść, zielona jaszczurka i sympatyczna sarna porównują swą urodę i urodę swych ogonów, gąsienica i zebra spór toczą o to, która z nich lepiej zna się na prawie drogowym i która może się poszczycić wyższą kulturą jazdy, ślimak i byk próbują dowieść, czyje rogi są silniejsze, bażant i nietoperz się zaczepiają, 
a konik polny i żaba próbują sobie udowonić, że jedno od drugiego ma dłuższy skok. Wszyscy bohaterowie poważną rozmowę przekształcają w literackie i życiowe sympozjum. Rym w drugim i czwartym wersie, rytm, dowcip, żartobliwość, humor, ślady znanych przysłów zorganizowane w czterowierszowych strofach z niezachwianym sześciozgłoskowcem czynią te wiersze łatwymi do zapamiętania, żywymi i zabawnymi.

Dziecko jako postać literacka jest prawdziwą innowacją w twórczości baśniopisarza Lessinga, gdyż zazwyczaj najmłodsi nie zajmują w baśniowych fabułach uprzywilejowanego miejsca. W utworach Kujundżiskiego bohater dziecięcy kryje się za wszystkimi zwierzętami, owadami, robaczkami, ziołami, które w jego obrazach lirycznych i baśniowych opowieściach nazywane są zdrobniale i pieszczotliwie: mróweczka, piesek, świerszczyk, kotek, deszczyk, kurczaczek, sarenka, świnka, smoczątko, myszka, kogutek, zajączek, wróbelek.

$\mathrm{W}$ dziele tym jest też parę smutnych tekstów, ale Kujundżiski, jak zresztą Hans Christian Andersen, nigdy nie jest pesymistą. Zawsze z jego wierszy wyłania się nadzieja, że - mimo wszelkich trudów życia - warto żyć, bo życie jest piękne i bogate, a ten, kto $z$ otwartym sercem przyjmuje małe i wielkie dary od życia, nigdy nie zostanie przez nie oszukany, że dobrzy ludzie właśnie dzięki dobru, które noszą w sobie, zawsze będą szczęśliwi. Wielki Andersen oprócz wykorzystania typowych dla ówczesnych baśni bohaterów zwierzęcych wprowadza również nowe postacie. W jego tekstach spotykamy więc ślimaki (Szczęśliwa rodzina), myszy (Zupa z kołka od kiełbasy), łabędzie i kaczki (Bociany, Brzydkie kaczątko). Do swoich baśni wprowadza jako bohaterów także rośliny, budując między nimi i ludźmi analogie dotyczące koloru czy postawy (np. Kwiatki Idalki, Sąsiedzi czy Ślimak i róża, w których pojawia się róża jako bohater). Andersen w swoich opowieściach ożywia też wiele przedmiotów, np. zabawki, różne figury, stare domy, przedmioty codziennego użytku, portrety, statuy, szafy, lustra, pojemniki, naczynia, jak w Dzielnym ołowianym żolnierzu, Czerwonych trzewiczkach i Starym domu. Podobną skłonność dostrzegamy w wierszach Kujundżiskiego, w których świerszcz skarży się, że mu bardzo gorąco, bocian stoi na jednej nodze, bo jest skąpy, wół płacze, bo nie podoba mu się imię, wrona w miejscu dołu pod starym orzechem chce zrobić morze, żubr nurkuje w basenie, a doberman poszukuje psa-ochroniarza.

„To wspaniałe, jak literatura może konkurować z zaciekłą wizualnością, która niekontrolowanie zdobywa świat dzieciństwa. A dydaktyczność literatury dla dzieci to tylko odwrotność mimesis, w jej istocie należy rozpoznać świat" - mówi Władowa w książce Literatura dla dzieci (Władowa, 2001, s. 17). Tom Kujundżiskiego I strofy rosna z powodzeniem dzięki poezji odkrywa przed najmłodszymi tajemnice życia, a jednocześnie wierząc w moc słowa, nie poddaje się wizualności. 


\section{Klucz do dzieciństwa jest w każdym człowieku}

Tom wierszy Skocz i przeskocz (Скокни, прескокни, 2017) autorstwa Wasyla Mukaetowa „nawleka” wersy, dążąc do jednego celu: by „Skoczyć i przeskoczyć! / By jak najszybciej rosnąć, / by jak najwięcej wiedzieć”. Jak w życiu! Tu rzeczywiście jest gdzie skoczyć i co przeskoczyć, co przeczytać i co doczytać, czego się nauczyć i czego douczyć, jeśli chce się dorosnąć naprawdę.

Centralnym wierszem zawierającym motto o dorastaniu jest ten opowiadający o babci - największej bajarce - która wyjeżdża w podróż, a wtedy dziecku pozostaje „skoczyć i przeskoczyć" - z ciekawskiego słuchacza bajek wyszytych z babcinych słów stać się prawdziwym czytelnikiem opowieści ukrytych w książkach splecionych ze słów. Do tego jednak, jak pisze Mukaetow, „Dom trzeba otworzyć, / alfabet trzeba przyswoić" (w: Odnajduje się, opowieści znajduje, mac. Се снаоѓa, сказни пронаоѓa).

Wiersze Skocz i przeskocz reprezentują przebudzone dziecko w autorze, wszak traktują o pewnym autorze, który nie chce przestać myśleć jak dziecko, o autorze, który umie rozbawić, ale też uczyć dziecko, bawiąc, o autorze, który uczy, grając słowami, i gra, mówiąc mądrze. Jak śpiewa poeta: „Tak było zawsze / i w każdym wieku. / Klucz do dzieciństwa / jest w każdym człowieku! (Klucz do dzieciństwa).

Tom Skocz i przeskocz próbuje złapać rytm dzisiejszego dziecka, ale też opowiedzieć mu o jego rówieśniku z przeszłości, z czasów jego rodziców i dziadków. Czytelnik odwiedza więc dzięki wierszom odpust czy cyrk, dowiaduje się, jak się mierzy czas zegarkiem ręcznym, telefonem, ale też klepsydrą, słyszy pieśni traktujące o obrzędach lub starych rzemiosłach. Wśród utworów znaleźć można te mówiące o pasterzach, rybakach, kucharzach. Do tańca zapraszają nas:

- pszczółka, główna bohaterka wiersza $Z$ kwiatka na kwiatek, która oprócz tego, że stanowi część przyrody, rozpoznawalna jest też przez dziecko jako pieczątka przybijana na ręce lub w zeszycie zamiast oceny do dziennika, by dać uczniowi do zrozumienia, jak zresztą czy tamy w ostatnim wersie, że „On jest pracowity jak pszczoła!";

- pająk, który nie wyplata sieci, lecz porządkuje samochody na miejskich ulicach (Pająk w środku miasta - Пajaк cpede гpad);

- wózek w supermarkecie, który jest nie tylko koszem na zakupy, ale przede wszystkim niezwykłym środkiem transportu (Kupujesz, szusujesz - Cu пазариш, се возиш);

— winda, która jest magicznym wehikułem, gdyż lata w dół i w górę jak rakieta (Podróż na piętro - Се возиш на кат);

— pokój dziecięcy, który wielokrotnie staje się ogromnym statkiem pirackim ( $\mathrm{Za}$ drzwiami - piraci - Зад нашите врати - пирати);

- parasol przeciwsłoneczny - kolorowa restauracja (Pływaja - Тие пливаaт). 
Za największy grzech literatury dla dzieci uważa się właśnie jej dydaktyzm, choć sama ta cecha nie jest zła. Powtórzmy zatem słowa Władowej: „To wspaniałe, jak literatura może konkurować z zaciekłą wizualnością, która niekontrolowanie zdobywa świat dzieciństwa. A dydaktyczność literatury dla dzieci to tylko odwrotność mimesis, w jej istocie należy rozpoznać świat" (Władowa, 2001, s. 17). Mukaetow ciągle więc uczy, nawet gdy śpiewa o ołówku i gumce, które "cuda wypisują, / błędy poprawiają. / Dlatego w piórniku, dzielnie wyczekują!" (Ołówek i gumka - Не може молив без гумичка).

Autor uchyla drzwi swym bohaterom, by ci swobodnie wprowadzili się do jego poezji. W codziennej zabawie swoich wnuków poeta widzi wzloty i upadki popularnych bohaterów kreskówki Tom $i$ Jerry, a w każdym dziecku dostrzega małego (ukrytego) Pinokia. Mukaetow pisze o tym, że "nowe” dziecko jest przygotowane na "nowego" Czerwonego Kapturka, który swojej babci niesie ciastka i coca-colę, zabierając ze sobą tablet i telefon. W jednym swoim wnuku widzi nową wersję popularnego Bena 10, a w drugim - zupełnie nowoczesnego Kapitana Haka $\mathrm{z}$ Piotrusia Pana.

Gry jednak na tym się nie kończą. Z dziecięcego pokoju nurkujemy w podwodny, morski świat, a bohaterowie bajek o małej Syrence Andersena czy o rybce Nemo Walta Disneya zyskują towarzyszy w wersach Mukaetowa. Pojawiają się: zły skorpion (którego autor określa mianem komara w oceanie), jeżowce, ośmiornica wielkooka i o uśmiechniętej paszczy i wieloryby, i rekiny, a wszystkie one szczęśliwie ożywają w szalonych zabawach obu wnuków pisarza. Z morskiego świata czytelnik przenosi się do wersów o lwach, które wciąż jeszcze możemy obserwować na naszej planecie, ale też o przeróżnych i przedziwnych, prehistorycznych gadach, które - prócz podręczników i książek — żyją właśnie w poezji Mukaetowa, wciąż wywołując emocje.

Dobra literatura dla dzieci kładzie nacisk na wrażliwe i silne dorastanie. Przenosi czytelnika z dzieciństwa w dorosłość lekko i niezauważalnie. W tym tkwi także jej przesłanie - pomóc małemu człowiekowi przejść przez złożony proces samopoznania i pokazać, że w tym procesie nie jest sam.

Jeszcze parę słów o macedońskiej literaturze dla dzieci (zamiast wniosków)

Należy ponownie sięgnąć do źródeł literatury, aby dopowiedzieć jeszcze kilka słów. Slawko Janewski „kładzie fundamenty pod literaturę dla dzieci i literaturę dla dorosłych", mówi Władowa (Władowa, 2001, s. 19), myśląc o literaturze macedońskiej, a odwołując się przede wszystkim do prozy Ulica wydanej w $1950 \mathrm{roku}^{3}$.

${ }^{3}$ W tym kontekście należy podkreślić fakt, że Cukrowa opowieść Slawka Janewskiego jest prawdziwym przykładem autorskiej/artystycznej bajki, którą porównać można do takich dzieł światowej literatury jak Pinokio Carla Collodiego (zob. Mojsowa-Czepiszewska, 2000, s. 196-221). 
Nie należy jednak zapominać o wszystkich tych, którzy ramię w ramię z nim tworzyli tę literaturę. Warto wymienić choćby Wancza Nikolewskiego, Wasyla Kunoskiego, Borysa Bojadżiskiego, Gligora Popowskiego, Canego Andreewskiego, Widoego Podgoreca. Pamiętać trzeba, że prawie wszyscy, oprócz Janewskiego, najpierw byli nauczycielami, a potem pisarzami przede wszystkim dla dzieci. Winniśmy otwarcie powiedzieć, że wraz ze Slawkiem Janewskim zarówno Wanczo Nikoleski, jak i w szczególności Wasyl Kunoski położyli podwaliny pod macedońską literaturę dla dzieci.

Białe cyganiątko, Czarodziejskie siodełko, Mice, Duzi i mali, Druga zmiana, Marta (mас. Белото циганче, Волшебното самарче, Мице, Големи и мали, Втора смена, Марта) to prawdziwe perełki macedońskiej literackiej skarbnicy dla dzieci. Porażający jest jednak fakt, że literatury dla najmłodszych czytelników dziś w Macedonii wydaje się naprawdę niewiele, może z wyjątkiem ostatnich kilku lat. Pisarze nie tworzą dla dzieci, a ten rodzaj literatury nie jest traktowany poważnie. Nakłady są małe, nie ma wsparcia mediów, a autorów postrzega się jako pisarzy drugiej kategorii.

Jedną z prób zmiany tej sytuacji było zorganizowanie w lutym 2010 roku debaty zatytułowanej Macedońska literatura dla dzieci i młodzieży dzisiaj, która odbyła się w Centrum Kultury „Feniks”. Debatę prowadziła Maria Tauszanska, redaktorka „Kolibra” - jedynego na rynku prasy w Macedonii dodatku dla dzieci do gazety codziennej „Nowa Makedonija”. Uczestnikami debaty byli: Gorjan Petrewski, Welko Nedelkowski i Wanczo Polazarewski, Pero Milenkowski, dawny długoletni redaktor „Kolibra”, Maria Todorowa ${ }^{4}$, tłumaczka i współzałożycielka wydawnictwa Vermilion, publikującego literaturę dla dzieci, Mile Topuz, ilustrator książek dla dzieci, i Hristo Petreski, który w 2009 roku otrzymał nagrodę Stowarzyszenia Pisarzy Macedońskich im. Wancza Nikoleskiego za swoją książkę dla dzieci Mądrym nie potrzeba stopni, by się wspiać.

Bierność, izolacja, brak ciągłości oraz twórczego i pokoleniowego odświeżenia, stereotypy, ograniczenie lokalne... Taki jest niestety stan literatury dla dzieci i młodzieży w Macedonii, z czym zgodzili się uczestnicy debaty, ubolewając, że przy okazji rozmowy o tejże literaturze nie można użyć pojęć, takich jak: „wolna myśl”, „kreatywność”, „edukacja”, „tolerancja dla inności”, „duchowa rywalizacja”, „postęp”. Wanczo Polazarewski, który będąc pisarzem dla dzieci oraz przez wiele lat pracując jako redaktor pisma dla nastolatków „Tin szema”, uważa, że pisanie dla najmłodszych jest pracą szalenie odpowiedzialną i wymagającą uważności. „Napisanie wartościowego dzieła to wyzwanie. Każdy autor powinien odnaleźć dziecko w sobie, nie pisząc jednak o swoim dzieciństwie, lecz podejmo-

4 Todorowa jest jednym $\mathrm{z}$ niewielu autorów, którzy podejmują temat literatury dla dzieci z punktu widzenia teorii. W swojej książce Литературата за деца и културната разноликост (2010) zajmuje się teoretycznymi aspektami motywu inności w literaturze dla dzieci wydanej po 2001 roku w Macedonii. 
wać aktualne dla dzisiejszych pokoleń tematy" - mówi Polazarewski ${ }^{5}$ Według niego, ważne jest podejście do dziecka i traktowanie go z szacunkiem, jako osobę i równoprawnego partnera w rozmowie. Polazarewski widzi przyszłość literatury dla dzieci w jej uwspółcześnieniu oraz wykorzystaniu Internetu w sposób dydaktyczny. „Dla przyszłych pokoleń powinniśmy bocianowi Siljanowi [bohater literacki - N.Ł.] przyprawić elektroniczne skrzydła, by łatwiej mógł wlecieć w XXI wiek" - twierdzi Polazarewski.

Welko Nedelkowski, który jest autorem bardzo popularnych w swoim czasie scenariuszy seriali dla dzieci, kręconych na motywach jego powieści Druga zmiana i Maki wzdłuż torów, uważa, że macedońska literatura dla dzieci, mimo że jakością dorównuje literaturze europejskiej i światowej, jest anonimowa, ponieważ nie jest prezentowana na zewnątrz. Wskazał wiele książek wartych pokazania w świecie i zwrócił uwagę na fakt, że do tej pory nikt nie podjął się np. wyprodukowania filmu dla dzieci na ich podstawie, jak to się stało w przypadku Harry’ego Pottera ${ }^{6}$. Pół wieku macedońskiej kinematografii nie może się pochwalić filmem dla dzieci, a w kraju funkcjonują tylko dwa teatry, które w swym repertuarze mają przedstawienia dla najmłodszej publiczności. Nikt do tej pory nie podjął się napisania powieści o życiu legendarnego Króla Marka ${ }^{7}, \mathrm{z}$ której potem mogłaby powstać filmowa wersja w stylu Władcy pierścieni.

Hristo Petrewski z wydawnictwa Feniks twierdzi, że literatura dla dzieci jest na świecie jedną z najbardziej komercyjnych literatur, ściśle powiązanych z przemysłem filmowym, zabawkowym, ale w Macedonii takie zjawisko jest niemożliwe ze względu na niewielki i specyficzny rynek książki. Dla Gorjana Petrewskiego, najpopularniejszego pisarza dla dzieci w Macedonii, autora popularnej Marty, nastolatkowie to najszczersi czytelnicy i właśnie dlatego autor powinien wiedzieć, jak przykuć i zatrzymać ich uwagę.

${ }_{5}^{5}$ Zob. Каде се загубија приказните во „Нова Македонија”, бр. 21917, z 23.02.2010.

${ }^{6}$ W tym kontekście należy wspomnieć: serial telewizyjny z 1975 roku pt. Czarodziejskie siodełko (Волшебното самарче) w reżyserii Aco Aleksowa z Igorem Dżambazowem w roli głównej, następnie macedoński serial dla dzieci i młodzieży Druga zmiana (Втората смена) nakręcony w 1988 roku na motywach powieści Welka Nedelkowskiego (częściowo dostępny w Internecie) oraz serial telewizyjny Duzi i mali (według powieści Boszka Smacioskiego z 1966 roku) w reżyserii Duszka Naumoskiego, kręcony w latach 1999-2000.

7 Należy wziąć pod uwagę, że poemat heroiczny - patrząc przez pryzmat procesu tworzenia poetyckiej biografii bohatera eposu - traktowany jest tu jako prototyp powieści. Zbiór stu siedmiu pieśni i czterdziestu jeden legend i podań opowiadających o Królu Marku, opisanych przez Kirila Penuszlinskiego w publikacji Król Marko - legenda i rzeczywistość, przejętych z różnych źródeł (od braci Miladinowów, Cepenkowa, Werkowicia, Szapkarewa, Ikonomowa i innych), stanowi podstawę do sportretowania tego bohatera. Przykład uwspółcześniowej legendy odnajdujemy w książce Opowieść o Wilhelmie Tellu Jürga Schubigera, która zdobyła szwajcarską nagrodę dla książki dla dzieci w 2005 roku. Nawet na okładce książki jako przesłanie czy też rodzaj reklamy widnieje napis głoszący: „Legenda o Wilhelmie Tellu w Szwajcarii jest jak legenda o Królu Marku w Macedonii”. 
Szczególnie należy jednak podkreślić sąd Wancza Polazarewskiego o potrzebie zwrócenia się pisarzy w stronę nowych mediów. „Dziś dziecko ma przed sobą nieskończoną ilość elektronicznych dróg, które nie znają granic. Oferują one młodemu czytelnikowi inny typ lektury. Lektury, która przebiega w zgodzie z nowym czasem i jest znacznie atrakcyjniejsza" - twierdzi Polazarewski, dodając:

W czytaniu tym nie ma podwórka, nie ma ulicy do zabawy, nie ma kości... dlatego bezowocne są nostalgiczne westchnienia nad dawnymi czasami, które już odegrały swoją rolę. Dziś dzieci mogą jedynie czuć się zdezorientowane ciągłym upieraniem się przy tej nostalgii. Dziś młodzi czytają zwiastuny najnowszych filmów, dziś dzieci i młodzież są głęboko zanurzone w świecie Alicji. Nie są jedynie biernymi odbiorcami, są uczestnikami budowania swojej kultury,

twierdzi Polazarewski (2010).

Tode Iliewski, laureat nagrody Stowarzyszenia Pisarzy Macedońskich im. Wancza Nikolewskiego za najlepszą książkę dla dzieci w 2010 roku, twierdzi, że powstanie festiwalu literatury dziecięcej w Macedonii, sądząc po światowych i regionalnych doświadczeniach, mogłoby zmotywować zarówno autorów, jak i czytelników. Festiwale w Bułgarii, Serbii czy Chorwacji to tylko część corocznych wydarzeń poświęconych dziecku i słowu pisanemu.

Trzeba powiedzieć, że kultowa książka Zoki Poki autorstwa Oliwery Nikolowej, wydana w 1963 roku, nie doczekała się swojej godnej następczyni. Zoki Poki wciąż nie może odejść na emerytyrę. Przyczyna jego ogromnej popularności leży najpawdopodobniej w kwestii połączenia tego, co rzeczywiste i magiczne - mówi o tym sama autorka, podkreślając, że opowieść ta budowana jest na podstawie obserwacji dziecięcej codzienności, przy czym zadaje sobie/nam kluczowe pytanie: „[...] czy obserwacja może przerosnąć w literaturę, jeśli nie przyłożymy do niej czułej dłoni fantazji” (cyt. za: Drugowac, 1996, s. 335). Tak więc według autorki to jednoczesność dwu projekcji, dwu perspektyw przyczynia się do sukcesu i popularności tego opowiadania.

Miodrag Drugowac w swojej książce Macedońska literatura dla dzieci i młodzieży w następujący sposób charakteryzuje z dzisiejszego punktu widzenia klasyczne już dzieło macedońskiej Nikolowej:

W Zokim Pokim w sposób spontaniczny uzgadniają się atrybuty tego, co rzeczywiste i fantastyczne, prawdziwie i wymyślone, by zatriumfowała gra, dzięki której realizują się poetyckie zadania nowoczesnej prozy dla dzieci. Każda opowieść ma swój infantylny ciąg wydarzeń, które jednak następują jedno po drugim w ramach pewnego standardu, gdzie na pierwszy plan wysuwa się aspekt dziecięcy i w którym nieprzerwanie króluje duch dzieciństwa. Każda opowieść dowodzi, że gra służy zabawianiu dziecka. Jednak nawet najbardziej zabawna lektura powinna skłaniać do przemyśleń, gdyż w przeciwnym razie to, co napi- 
sane, przestaje mieć sens, stając się grą samą w sobie, przysłaniającą prawdziwy, twórczy zamiar autora, jego ideę, cel, pedagogiczny i edukacyjny sens opowieści. Drugowac, 1996, s. 335

W rzeczywistości więc Zoki Poki stanowi dojrzałą i oryginalną prozę dla dzieci, bez wysiłku przyjmowaną przez małego/dziecięcego i dużego/dorosłego czytelnika.

W odpowiedzi na zainteresowania dzieci dotyczące nowych mediów (telewizji, komputerów i gier komputerowych) Zagorka Pop-Antoska dokonała w 2003 roku adaptacji książki Zoki Poki na miniserial z muzyką Toszego Pop-Simonowa, w reżyserii Aleksandra Ilieva ${ }^{8}$ emitowany w dziesięciu kilkunastominutowych odcinkach pod tym samym tytułem. W przygotowaniu jest również serial telewizyjny w reżyserii Aleksandra Popowskiego, realizowany dzięki finansowemu wsparciu Macedońskiej Agencji Filmowej.

Otwarte pozostaje jednak pytanie: dlaczego po pięćdziesięciu pięciu latach nikt nie podjął się stworzenia dla Zokiego nowego literackiego przyjaciela, spadkobiercy czy też kontrapunktu?. Brakuje inspiracji czy odwagi?

Naprawdę: dlaczego?

\section{Literatura}

Друговац М., 1996, Македонска книжевност за деца и младина, Skopje.

Идризовиќ М., 1988, Македонската титература за дещза, Skopje.

Мојсова-Чепишевска В., 2000, За уметничката сказна „Шекерна приказна“ во

Литературни преокупации, Skopje.

Полазаревски В., 2010, Каде се загубија приказните. „Нова Македонија“. Skopje, бр. 21917, 23.02.2010.

Тодорова М., 2012, Преведувағето за деца како меѓукултурна комуникација, Skopje.

Владова J., 2001, Литература за деца, Skopje.

Tłumaczenie z języka macedońskiego na język polski: Natalia Łukomska

${ }^{8} \mathrm{https} / /$ www.youtube.com/watch?v=y3yGc4XVkRg [data dostępu: 26.09.2018] - pierwszy odcinek; https://www.youtube.com/watch?v=kD_YxkF-niw [data dostępu: 26.09.2018] — drugi odcinek; https://www.youtube.com/watch?v=H4T7Z6oSaRU [data dostępu: 26.09.2018] — trzeci odcinek; https://www.youtube.com/watch?v=yTHeVwnyGzM [data dostępu: 26.09.2018] — czwarty odcinek; https://www.youtube.com/watch?v=57E2SgaXiPs [data dostępu: 26.09.2018] — piąty odcinek; https://www.youtube.com/watch?v=oqtqZKoeVRA [data dostępu: 26.09.2018] — szósty odcinek; https://www.youtube.com/watch?v=AXNRABqHl3Q [data dostępu: 26.09.2018] — siódmy odcinek; https://www.youtube.com/watch?v=gtR_qmO3JHk [data dostępu: 26.09.2018] — ósmy odcinek; https://www.youtube.com/watch?v=FOZ-5lVkpl0 [data dostępu: 26.09.2018] - dziewiąty odcinek; https://www.youtube.com/watch?v=IxLMGBuJ3v4 [ata dostępu: 26.09.2018] — dziesiąty odcinek. 
Natalia Łukomska - doktor nauk humanistycznych, lektor języka polskiego jako obcego na Uniwersytecie Świętego Cyryla i Metodego w Skopje, tłumaczka z języka macedońskiego. Jej zainteresowania naukowe to: współczesny język polski ze szczególnym uwzględnieniem pragmatyki językowej, język w aspekcie glottodydaktycznym, gramatyka porównawcza języków słowiańskich, współczesne języki czeski i macedoński, teoria i praktyka przekładu. Pracę doktorską poświęciła imiesłowom nieodmiennym w języku polskim i macedońskim w aspekcie przekładowym oraz glottodydaktycznym.

e-mail: natalia_lukomska@o2.pl 
